\title{
Whither the Liberal International Order? Authority, Hierarchy, and Institutional Change
}

\author{
David A. Lake
}

he liberal ointernational order (LIO) formed and led by the United States
after 1945 has been increasingly challenged in recent years. ${ }^{1}$ Embedded
in a series of international institutions, including the North Atlantic Treaty Organization (NATO), the Organisation for Economic Co-operation and Development (OECD), and the Group of Seven $\left(\mathrm{G}_{7}\right)$, the LIO aspired to be universal but in practice has always been limited to "core" states in Europe, North America, and Northeast Asia. The United Nations was the institution that came closest to realizing the universalism preached by liberals, but was effectively gutted by the Cold War competition between the veto-wielding superpowers. Other international institutions also possessed broad membership, such as the General Agreement on Tariffs and Trade (GATT), later replaced by the World Trade Organization (WTO), and the International Monetary Fund (IMF) and World Bank, but were stratified into core members that set the rules and peripheral members that were either bound by the rules or treated as wards that could not participate fully in the governance or benefits of the respective organizations.

Though the LIO has been challenged in the past-most dramatically by the decline of U.S. hegemony in the 1970 s as a result of the oil shocks and the New International Economic Order, among other things-it has proven remarkably resilient. Indeed, it enjoyed a major resurgence after the end of the Cold War, when, as Francis Fukuyama famously declared, the end of history arrived and liberalism was the only remaining game in town. ${ }^{2}$ Yet, today, populist movements and unilateral actions by leaders in core countries challenge at least some of the

Ethics \& International Affairs, 34, no. 4 (2020), pp. 461-471.

(c) The Author(s), 2020. Published by Cambridge University Press on behalf of the Carnegie Council for Ethics in International Affairs. This is an Open Access article, distributed under the terms of the Creative Commons Attribution licence (http://creativecommons.org/licenses/by/4.o/), which permits unrestricted re-use, distribution, and reproduction in any medium, provided the original work is properly cited.

doi:10.1017/So892679420000611 
principles at the heart of the LIO. The United States, to take one recent and potent example, has completely abandoned its international leadership role during the current COVID-19 pandemic. At the same time, deepening the crisis, core states are confronted by a major external rival: China. This time might really be different.

Without being too pessimistic, I expect the LIO will survive but will retract to its original core states, shedding some of its universal pretensions. States that remain within the liberal order, in turn, will compete with an alternative Chinese-led international hierarchy built around all or part of the current Belt and Road Initiative countries. The competition between these two orders will be similar, though of course not identical, to the Cold War struggle between the United States and the Soviet Union. ${ }^{3}$ While international institutions will be able to facilitate cooperation and may be resilient, they will not be able to bridge this emerging divide sufficiently to forestall conflict and, in any event, will not be sufficiently robust to prevent a new cold war. This brief essay sketches this argument and concludes with some possible ways of moderating future conflicts.

\section{INTERNATIONAL INSTITUTIONS AND THE WEST}

There were three pillars to the LIO. First, states that adhered to this order were required to resolve disputes with other "member" states through strictly peaceful means-in conjunction with the third pillar described below, producing the so-called democratic peace-and act collectively to deter threats from states outside the order, leading to the so-called long peace. ${ }^{4}$ This first pillar did not imply the absence of hard bargaining between members; only that they would turn their substantial militaries not toward one another but toward other states outside of the LIO. Though the idea was perhaps premature at the time he was writing, or just prescient, Karl Deutsch and colleagues proclaimed in the 1950 s that the North Atlantic states had formed a pluralistic security community. ${ }^{5}$

The second pillar was that states wishing to be part of the LIO were to open their markets for international goods and capital flows. Many of the economic institutions associated with the LIO acquired broad membership, though never from communist countries, during the Cold War. Nonetheless, developing countries were always treated as second-class members, as deficient in some way and requiring regulation from their "betters," or "grants" of favorable terms exempting them from the norm of reciprocity. Nonetheless, these institutions facilitated 
globalization by reducing barriers to trade and opening international capital markets, thereby producing unprecedented levels of prosperity, dramatically increasing income growth for core states, and bringing more people out of absolute poverty than ever done in human history.

Finally, states within the LIO were to be democratic and respect human rights. These rights were universal in principle, but they always applied mostly to core states-though over time selective benefits provided by core states for protecting human rights helped spread the norms more broadly. ${ }^{6}$ Though the Universal Declaration of Human Rights (UDHR) includes a long list of principles, only a handful of liberal rights gained special status as being nonderogable and thus worthy of broad enforcement by the core states. ${ }^{\text {? }}$

After 1945, U.S. leadership within the LIO rested on a convergence of interests between Washington and its client regimes and multilateral institutions. This convergence simultaneously constrained and lent credibility to the authority of the United States. Critically, by 1947 or so, the United States, Western Europe, and Japan became convinced that they were facing a common threat from the Soviet Union. Whether or not the Soviet Union truly was an imperialist and expansionist threat to the world order remains an open debate among historians and political theorists. At the very least, even if through a series of missteps and misperceptions, Western countries came to believe they faced a threat from communist Russia, which caused them to sublimate their differences and form a united front. ${ }^{8}$ In turn, devastated by the war, the economies of Europe and Japan were rebuilt with U.S. aid to accord with broad principles of comparative advantage and integrated into an open international economy. With privileged access to the dynamic U.S. market dangled in front of the axis countries, which had only years earlier sought their own exclusive economic zones, a consensus quickly formed among the core countries in favor of freer trade and open international markets. ${ }^{9}$ With these security and economic principles in place, the United States convinced centrist and center-right governments in all of these now subordinate countries to adopt policies favored by Washington. Thus, U.S. rule, or "leadership"- the euphemism Americans prefer-was compatible with democracy. This truly was, as Geir Lundestad famously called it, an "empire by invitation." 10

International institutions played a central but not determinative role in building this LIO. As theory predicts, the institutions of the LIO facilitated cooperation by defining the rules by which the game of international politics would be played among its adherents, providing information and reducing transaction costs. ${ }^{11}$ 
The institutions also embodied rules preferred by the United States, privileging its policy preferences over possible alternative principles. Because popular preferences in Europe and Japan by this point largely converged with those of the United States, U.S. rule was invisible. The liberal bias instantiated into the rules of the LIO went almost unnoticed by Western scholars who shared the underlying norms and preferred, instead, to focus on their Pareto-improving effects. And perhaps most importantly, the multilateralism of the LIO's institutions served to limit the power and authority of the United States, if only by giving other members some voice over U.S. actions. ${ }^{12}$ This limitation actually served to legitimate U.S. authority, transforming what might otherwise have been understood as coercion into rightful rule. ${ }^{13}$

After the Cold War, the interests of the United States and the other members of the LIO, especially those in Europe, began to diverge. This is, in my view, the key change that is, today, fracturing the LIO. After 1989, Europe turned inward, incorporating the former East European states into the European Union, building the eurozone, and deepening European integration overall. Building on their own experience, Europeans came to believe that economic and political integration and international institutions could overcome nearly all obstacles to international cooperation. Conversely, the United States attempted to extend its international hierarchy into new regions, principally the Middle East, to create a new world order. In seeking to expand the LIO on infertile soil, the United States has relied on the biggest tool in its toolbox: military force. Having built a really big hammer during the Cold War, every problem in the world looks to Washington as if it can be solved with more nails, leading to three major U.S. wars since 1991: the Persian Gulf War, which aimed to protect norms of territorial integrity and the peaceful resolution of disputes, and the wars in Afghanistan and Iraq, which aimed, in part, to promote democracy. Whereas Europe sought to deepen international institutions, the United States did not attempt to institutionalize its role in the Middle East, though it has on occasion wrapped its aspirations for authority in ad hoc coalitions. ${ }^{14}$ Rather, it has adopted far more coercive and unilateralist strategies in dealing with the region. Though overly simplistic, Robert Kagan captured the difference between allies now on different paths with the phrase "Americans are from Mars and Europeans are from Venus." ${ }^{15}$

This divergence in interests between the United States and Europe intersects with and is, perhaps, both exacerbated by and manifested in a new wave of populism across the core states. Though populists from different countries are often 
similar in that they espouse nationalist ideologies and demand a return of their country's sovereignty (supposedly lost to various international organizations), populism itself has a variety of origins and can take myriad forms. In Europe, populism largely appears to be a reaction to immigration, especially to the large number of refugees from the Middle East and North Africa. European populists have not turned against free trade, however. Even Brexit, the clearest populist turn against the existing economic order, was sold by its proponents not as protection for British industry but as an opportunity to negotiate even more beneficial trade agreements with the United States and other countries. In the United States, despite President Donald Trump's famous cry to build a wall, populism is more clearly a response to trade and has taken a more protectionist turn, the area where U.S. presidents have more policy discretion. ${ }^{16}$

And although populists invariably have nationalist tendencies, in the United States populism has also merged with unilateralism. There has always been a unilateralist strain in foreign policy in the Republican Party, reflected in the opposition of Senator Henry Cabot Lodge to the League of Nations and Senator Robert Taft to NATO and to the stationing of U.S. troops in Europe. This unilateralist approach to world affairs reached what was perceived (or hoped) by many to be an apogee during the Iraq War, when the United States eventually acted outside the authority of the United Nations. To nearly everyone's surprise, this unilateralism intensified even further under President Donald Trump, who abandoned a range of international agreements and institutions. Among other things, the president effectively stonewalled the WTO by refusing to approve members of its Dispute Settlement Body (rendering it impotent), withdrew the United States from the Paris Agreement, and stopped contributing to the World Health Organization just as it was called upon to tackle the unprecedented challenge of a global pandemic. The Trump worldview is that these types of agreements and institutions no longer serve to legitimate U.S. authority but are instead bothersome constraints on the pursuit of a self-defined national interest. This does not just reflect institutional neglect but also a real hostility toward institutions that constrain the freedom of action of the United States.

\section{INTERNATIONAL INSTITUTIONS AND THE REST}

The "liberal" in the LIO rests on the principle of human equality: that all humans are created equal and deserve the same rights and respect as all other humans. On this 
foundation, the LIO was intended to be universal. All countries that accepted the principles of the LIO could identify as part of the order and be recognized by others as part of the community of like-minded states. The United Nations is the only international institution that even partly lived up to this ideal of universal inclusion, though most clearly in its Westphalian articulations emphasizing sovereignty, the right of self-determination, and the principle of nonintervention. The more liberal part of that institution, embodied in the nonderogable rights of the UDHR, for instance, was and remains largely aspirational. In practice, the LIO and its institutions became an à la carte rather than fixed menu. A country could institute some market reforms and join the WTO, thereby benefiting from globalization and the gains from trade that followed, without accepting democracy or respecting human rights.

Though international institutions quickly became an integral part of the LIO, they never played the same role in mitigating competition and promoting cooperation between the United States and Soviet Union. Despite some international arms control agreements and shared norms, most institutions were built and functioned on only one side of the East-West divide. For years, the antagonism between the two superpowers hindered the United Nations' mission to promote peace and security around the world. This was made evident by the rapid expansion in the number of peacekeeping missions after 1991, following the conclusion of the Cold War. The Nuclear Non-Proliferation Treaty was a rare joint effort by the Americans and the Soviets to set rules for other states.

The turbulence surrounding the LIO today, in turn, is largely a "first world" problem. For those states loosely or only partially connected to the LIO, the debates within core states over collective security, trade, and democracy do not reverberate to the same degree. At the same time that international institutions are being questioned by core countries, they are proliferating throughout the rest of the world in the form of regional trade agreements, regional financial institutions, and even regional security agreements. Nonetheless, few of these institutions link countries across the developed-developing divide, the old East-West divide of the Cold War, or the emerging divide between the United States and China. Regionalism is not the same as internationalism.

\section{U.S.-China Competition and International Institutions}

A couple of years ago, I wrote that the United States and China were creeping toward a more competitive relationship. ${ }^{17}$ It now appears that, unfortunately, 
the two twenty-first century superpowers have turned a corner into a deeper and more risky geoeconomic rivalry. For nearly two decades, U.S. defense planners have been contemplating the effects of China's rise to great power status and preparing for the worst. In its first few months, the administration of President George W. Bush had begun to focus on China's military potential, but it was then distracted by the global war on terror. In winding down the wars in Afghanistan and Iraq, however unsuccessfully, President Barack Obama "pivoted" to Asia in response to the same worry. China has played into this concern by vigorously asserting its sovereignty over the South China Sea. What would have otherwise been manageable geopolitical tension regarding these developments has exploded thanks to President Trump's trade war, however. The reciprocally punishing tariffs worsen relations, of course, but perhaps more important has been the 2018 embargoes on sales of semiconductor chips made with American equipment to ZTE, China's second-largest electronics firm, and in 2020 to Huawei, China's largest electronic firm. If the United States was worried about the "Made in China 2025" industrial policy aimed at supporting advanced manufacturing in the country, it has succeeded only in forcing China to accelerate its upgrading - perhaps to a China 2021 program.

With the "China hawks" now on the ascent in Washington, with President Trump and other high administration officials having blamed Beijing for the pandemic, and with President Xi Jinping's nationalism ever more evident, the two economic powerhouses have been transformed into geoeconomic rivals, each preparing to decouple economically from the other as much as possible and seeking to build new economic blocs. The United States has already begun this process by negotiating the now aborted Trans-Pacific Partnership (TPP) aimed to constrain China and, more importantly, demanding that its allies not use Chinese equipment in their ${ }_{5} \mathrm{G}$ networks. In turn, China is actively building international ties through its Belt and Road Initiative (BRI). Though in principle not closed to Western participation, the BRI ties many of its loans and investments to China and encourages new dependencies that might be exploited for political influence in the future. As China seeks to develop its high-tech industries, moreover, it will at least initially need to subsidize production to move down its cost curve and may take advantage of political ties to promote exports, which allow it to further exploit economies of scale. The BRI countries will be natural targets of this export drive. My expectation is that within the next few years we will see the emergence of two geoeconomic blocs, one led by the United States and the other by 
China. With tongue only somewhat in cheek, I think of these as the "Western $5 \mathrm{G}$ " world and the "Huawei $5 \mathrm{G}$ " world, with the latter composed of Belt and Road countries. Even if the United States and China resolve their tariff dispute (the firstphase agreement only halts the process of escalation; it does not resolve the underlying issues), I fear we are already on the path away from fair competition and toward deep rivalry.

There are few international institutions in place to mitigate this growing rivalry. Unlike during the Cold War, however, there are now a couple of important international institutions, principally the WTO, that bind both great powers (this is, in part, thanks to the aforementioned à la carte approach to the institutions of the LIO). Optimists once hoped that these shared institutions could serve to limit the emerging breakdown in relations, possibly turning China into if not a "responsible stakeholder," then at least a "stakeholder" in the LIO. But by actively undermining these shared institutions, President Trump has precluded this possibility. By carrying out the trade war completely outside the WTO, for instance, he both freed the United States to do whatever it wants and forgone any possible multilateral constraints it might have leveraged against China. It would have been far more effective, in my view, to mobilize other core states within the LIO under the umbrella of the WTO to negotiate jointly with China. Leveraging the legitimacy of the WTO, such a coalition could insist on new agreements in areas where the organization's rules do not currently limit China's policies on subsidies, foreign direct investment, and intellectual property, and could pressure Beijing to remain a member in good standing. Trump's unilateralism has undercut this option, at least to date. Even those international institutions to which both the United States and China belong will likely be blown apart as their rivalry deepens.

To establish and maintain their dominance over their respective economic blocs, both the United States and China will revive old institutions and build new ones to strengthen their own authority and limit the other country's. Though China has demanded and received somewhat greater vote shares in Western-based institutions such as the IMF, it still does not play a role commensurate with its economic size. As a result, it may be seeking to build a parallel regional structure that more clearly represents its interests, with the Asian Infrastructure Investment Bank being perhaps an early example-one that, I think, the United States erred in not joining when it was first invited. The United States seems to be responding in kind with the proto-TPP and the new 
United States-Mexico-Canada Agreement (USMCA) as fledgling examples. These regional institutions, however, will do little to bridge the divide between Washington and Beijing. To extend the analogy from above, the new faster $5 \mathrm{G}$ Internets will simply not connect to each other. Although it is possible that China's rise may still be peaceful, the lessons of history give plenty of reasons to worry. ${ }^{18}$ Though international institutions may bolster the power of the United States and China over their respective spheres of interest by helping to mobilize and direct the efforts of their client states, I see little that makes me hopeful these institutions will successfully limit conflict between blocs in the twentyfirst century.

In a world of blocs, most conflicts between the great powers arise over the borderlands. ${ }^{19}$ In the Cold War, all of the major crises between the United States and Soviet Union stemmed from where to draw the boundaries between their respective spheres of influence, including the Iran crisis of 1946, the Berlin crises of 1948-1949 and 1961, the Korean War, and the Cuban missile crisis in 1962. Only once the boundaries were largely settled and the two superpowers reached an understanding of where the lines were drawn was détente possible-and even then the period of warming was broken by the Soviet invasion of Afghanistan. None of these crises, it should be noted, were well managed by the international institutions that existed at the time.

Establishing the boundaries between U.S. and Chinese spheres of influence will likely be similarly fraught. While I expect rivalry at this point to be almost inevitable, how boundary disputes are handled is entirely open to diplomacy and effective management. Although my skepticism of the ability of international institutions to maintain peace in the face of conflicting interests is evident above, I believe international institutions can play a role here in clarifying the rules of competition and keeping the lines of communication open so that diplomacy can work. Leaders on both sides of this rivalry should start now by reviewing the rules governing the international economy to ensure that each retains some ability to trade and invest in countries in the other's sphere of influence. The United States and China should also be joined in this endeavor by other countries, which will otherwise be forced to choose one side over the other. This will require addressing deeper economic issues of subsidies, intellectual property rights, rules on investment, and more that currently lie outside the purview of existing institutions. The United States and China should also ratify and affirm, respectively, the UN Convention on the Law of the Sea, especially its principle of freedom of the 
seas. It would also be wise to negotiate limits on military fortifications near major oceanic routes. If I am correct that competition is turning to rivalry, many will push for increased defense expenditures to prepare for the possibility of future hostilities. We should also begin, however, to seek ways to limit and manage that rivalry so that misperceptions, overreactions, and unclear rules about appropriate behavior do not escalate into more serious conflicts.

\section{NOTES}

${ }^{1}$ This opening section draws on the essay "Challenges to the Liberal International Order," by David A. Lake, Lisa L. Martin, and Thomas Risse and the essays in the seventy-fifth-anniversary issue of International Organization (in progress).

${ }^{2}$ Francis Fukuyama, The End of History and the Last Man (New York: Free Press, 1992).

${ }^{3}$ David A. Lake, "Economic Openness and Great Power Competition: Lessons for China and the United States," Chinese Journal of International Politics 11, no. 3 (Autumn 2018), pp. 237-70.

${ }^{4}$ On the long peace, see John Lewis Gaddis, The Long Peace: Inquiries into the History of the Cold War (New York: Oxford University Press, 1987). On the democratic peace, see Bruce Russett and John R. Oneal, Triangulating Peace: Democracy, Interdependence, and International Organization (New York: W. W. Norton, 2001).

${ }^{5}$ Karl W. Deutsch, Sidney A. Burrell, Robert A. Kann, Maurice Lee Jr., Martin Lichterman, Raymond E. Lindgren, Francis L. Loewenheim, and Richard W. Van Wagenen, Political Community and the North Atlantic Area: International Organization in the Light of Historical Experience (Princeton, N.J.: Princeton University Press, 1957).

${ }^{6}$ For one example of selective benefits and democracy promotion, see Susan D. Hyde, The Pseudo-Democrat's Dilemma: Why Election Observation Became an International Norm (Ithaca, N.Y.: Cornell University Press, 2011). On improvements in human rights practices, see Christopher J. Fariss, "The Changing Standard of Accountability and the Positive Relationship between Human Rights Treaty Ratification and Compliance," British Journal of Political Science 48, no. 1 (January 2018), pp. 239-71.

7 David A. Lake and Wendy H. Wong, "The Politics of Networks: Interests, Power, and Human Rights Norms," in Miles Kahler, ed., Networked Politics: Agency, Power, and Governance (Ithaca, N.Y.: Cornell University Press, 2009), pp. 127-50; and Wendy H. Wong, Internal Affairs: How the Structure of NGOs Transforms Human Rights (Ithaca, N.Y.: Cornell University Press, 2012).

${ }^{8}$ Melvyn P. Leffler, A Preponderance of Power: National Security, the Truman Administration, and the Cold War (Stanford, Calif.: Stanford University Press, 1992).

9 For a fascinating study of how this played out in Japan, see John W. Dower, Embracing Defeat: Japan in the Wake of World War II (New York: W. W. Norton, 1999).

${ }^{10}$ Geir Lundestad, "Empire by Invitation? The United States and Western Europe, 1945-1952," Journal of Peace Research 23, no 3, (September 1986), pp. 263-277.

${ }^{11}$ Robert O. Keohane, After Hegemony: Cooperation and Discord in the World Political Economy (Princeton, N.J.: Princeton University Press, 1984).

${ }^{12}$ G. John Ikenberry, After Victory: Institutions, Strategic Restraint, and the Rebuilding of Order after Major Wars (Princeton, N.J.: Princeton University Press, 2001); and G. John Ikenberry, Liberal Leviathan: The Origins, Crisis, and Transformation of the American World Order (Princeton, N.J.: Princeton University Press, 2011).

${ }^{13}$ David A. Lake, "International Legitimacy Lost? Rule and Resistance When America Is First," Perspectives on Politics 16, no. 1 (March 2018), pp. 6-21.

${ }^{14}$ David A. Lake, Entangling Relations: American Foreign Policy in Its Century (Princeton, N.J.: Princeton University Press, 1999).

15 Robert Kagan, Of Paradise and Power: America and Europe in the New World Order (New York: Alfred A. Knopf, 2003), p. 3.

${ }^{16}$ Michael A. Bailey, Judith Goldstein, and Barry R. Weingast, "The Institutional Roots of American Trade Policy: Politics, Coalitions, and International Trade," World Politics 49, no. 3 (April 1997), pp. 309-38; and Helen V. Milner and Dustin Tingley, Sailing the Water's Edge: The Domestic Politics of American Foreign Policy (Princeton, N.J.: Princeton University Press, 2015).

17 Lake, "Economic Openness and Great Power Competition." 
${ }^{18}$ Dale C. Copeland, Economic Interdependence and War (Princeton, N.J.: Princeton University Press, 2015).

19 Lake, "Economic Openness and Great Power Competition."

Abstract: The liberal international order is being challenged today by populism and unilateralism. Though it has been resilient in the past, the current challenges from within the order are unprecedented. Without being too pessimistic, I expect the LIO will survive but retract to its original core states in North America, Europe, and Northeast Asia, shedding some of its universal pretensions. States that remain within the liberal order, in turn, will compete with an alternative Chinese-led international hierarchy built around all or part of the current Belt and Road Initiative countries. While international institutions can facilitate cooperation, they do not bridge this emerging divide sufficiently to forestall conflict and, in any event, will not be sufficiently robust to prevent a new cold war. As part of the roundtable "International Institutions and Peaceful Change," this brief essay sketches this argument and concludes with some possible ways of moderating future conflicts.

Keywords: authority, anarchy, liberal international order, new cold war, Belt and Road Initiative 